\title{
Sense and Nonsense in the Regulation of Equipment Financing Business in Ethiopia
}

\author{
Fekadu Petros Gebremeskel* \\ "Wealth does not lie on ownership but in the use of things." -Aristotle
}

\begin{abstract}
The discourse about equipment financing (financial leasing) business is not as to whether it is useful; but it is about how to create the best possible investment climate for the growth and expansion of the sector; that is how to maximize the economic gains in terms of facilitating alternative access to financing for businesses. Equipment financing or financial leasing is one of the alternative mechanisms of solving financing needs of businesses and individuals. It combines the attributes of lending and leasing, hence the name finance leasing or lease financing. It involves lending equipment (instead of lending the funds needed to purchase it) with the possibility of eventual ownership of the equipment by the borrower. Although equipment financing and leasing existed in Ethiopia over a long period of time, a detailed law on the subject was introduced only recently. However, the new regulatory regime which placed the financial leasing sector under the regulation of the National Bank of Ethiopia (NBE) did not stimulate the emergence of financial leasing companies as intended. It brought about the creation of big government owned leasing companies whose formation and operation is rather politically driven than supported by economic rationales. Much of the reason for the lack of enthusiasm from the private sector seems to be the discouraging regulatory environment. Therefore, the complex and cumbersome regulatory framework should be simplified if financial leasing companies are to flourish and play a meaningful role as alternative sources of financing.
\end{abstract}

\section{Key terms}

Equipment financing · Financial Leasing · Financial Regulation · National Bank of Ethiopia $\cdot$ Prudential Regulation

DOI http://dx.doi.org/10.4314/mlr.v13i1.2

This article is licensed under a Creative Commons Attribution-NonCommercialNoDerivs (CC BY-NC-ND)

\footnotetext{
* Fekadu Petros Gebremeskel (LL.B, LL.M) Assistant Professor, Addis Ababa University School of Law; Attorney at Law and Legal Consultant. Email: pehfekadu@gmail.com

The author thanks Mr. Frans Van Schaik, Mr. Jetu Edossa and the two anonymous external reviewers for their comments and suggestions towards the refinement of the manuscript. All errors remain mine.
} 


\section{Introduction}

Capital goods financing business (CGFB) ${ }^{1}$, also commonly known as equipment financing business, is a type of business that finances acquisition of equipment for businesses in a contractual arrangement whereby the financier (lessor) supplies the equipment required by the customer (lessee), and the latter pays rent plus interest for the duration of the period of the lease with eventual or possible transfer of ownership of the equipment to the lessee at the end of the lease. ${ }^{2}$ The types of businesses served by equipment financing sector are often start-ups, micro, small and medium level enterprises that cannot get financing from banks ${ }^{3}$ due to, among other factors, their inability to produce collateral. ${ }^{4}$

Frequently used acronyms:

Capital Goods Financing Business (CGFB)

Micro and Small Enterprises (MSE)

Micro-Finance Institutions (MFIs)

National Bank of Ethiopia (NBE)

Non-banking Financial Institutions (NBFI)

Small and Medium Enterprises (SMEs)

${ }^{1}$ Capital Goods Leasing Business Proclamation No. 103/1998, Federal Negarit Gazeta $4^{\text {th }}$ Year No. 27, 1998 introduced the modern form of equipment financing into Ethiopia; and Capital Goods Leasing Business (Amendment) Proclamation No. 807/2013, Federal Negarit Gazeta $19^{\text {th }}$ Year No. 60, 2013 has amended the earlier proclamation, Both proclamations use the term "Capital Goods Leasing Business-CGLB." This is because the proclamations cover operating leases. On the other hand the National Bank uses the term "Capital Goods Financing Business-CGFB" in all of the directives it issued so far probably with the view to make the terminology more fitting to its overarching mandate of regulating the financial sector. The terminology of NBE is appropriate because, NBE is not concerned with operating leases which are regulated by the Ministry of Trade (MOT). In reality various other terminologies are used in different literatures. To mention just a few, Equipment Financing, Asset Financing, Lease Financing, Financial Leasing, and so on. In this paper the writer uses the term "Equipment Financing" and "Financial Leasing" alternatively as these are the terms widely used in literature, and for their simplicity as well.

${ }^{2}$ Deloitte, 'Banking and Financial Services: Finance Leasing' Deloitte Limited, 2017p. 3, <https://www2.deloitte.com/content/dam/Deloitte/cy/Documents/financialservices/CY_FinancialServices_FinancialLeasing_Noexp.pdf> accessed on 1 August 2019

3 Asress Adimi Gikay (2017), 'Rethinking Ethiopian Secured Transactions Law through Comparative Perspective: Lessons from the Uniform Commercial Code of the US', Mizan Law Review 11 no.1:169.

${ }^{4}$ See, National Bank of Ethiopia, 'Capital Goods Finance Companies in Ethiopia: An Overview' Birritu Magazine 118 (2014), p. 32 for the assertion that equipment financing scheme simplifies the collateral related problems of SMEs. See also Economisti Associati and BKP Development, 'Access to Finance in Ethiopia: Policy, Regulatory and Administrative Remedies', WBG/IFC, p. 24, 33, 35 (2014). According to this survey problems associated with collateral were found to be the second most pressing challenge 
Because the equipment supplied through leasing serves the function of collateral $^{5}$, those businesses that cannot get credit from banks for lack of collateral can be served by financial leasing companies.

The first section of this article highlights the features and indicators in the regulation of equipment financing. Section 2 deals with the conceptual and theoretical underpinnings of the regulation of equipment leasing in Ethiopia, namely, the broader historical and theoretical literature on the evolution, types of financial leasing companies and regulatory approaches for equipment financing businesses. It compares financial sector firms especially banks and equipment leasing firms with the view to assessing the regulatory regime for the latter by contrasting it with the regime for banks. In Section 3, an evaluation of the regulatory system of financial leasing sector is made based on five indicators and building upon the theoretical and conceptual analysis.

\section{Regulation of Equipment Financing and Core Indicators of Regulatory Effectiveness}

Financial leasing is one of the alternative mechanisms of solving financing needs of businesses and individuals along with bank loans. Essentially it is an activity of lending equipment instead of lending the funds needed to purchase it with the possibility of eventual ownership of it by the borrower. In spite of these parallels between financial leasing and bank lending, the business of financial leasing is not the same as that of lending. Thus, the regulatory design for leasing cannot be a replica of the banking regulatory architecture.

In Ethiopia, equipment financing businesses are part of non-banking financial institutions (NBFI) which is subject to NBE regulation. NBFI are financial companies engaged in economic activities akin to banking -"but are not classified as deposit takers." "Under Ethiopian law, the place of MicroFinance Institutions (MFIs) is equivocal from this perspective if one strictly applies this definition. They are deposit takers, and hence technically outside the scope of NBFIs; on the other hand MFIs are not banks, and thus functionally can be considered to be NBFIs. In any case, it is generally assumed that the regulation of NBFIs should be less cumbersome than the regulation of banks. The regulation of these institutions is usually, but not always, vested in

next to inadequacy of loan size. The problems in relation to collateral are basically two: (i) very limited types of assets are accepted as collateral; and (ii) overcollateralization, i.e., when accepted, the value of the collateral is required to be substantially more than the amount of the loan requested.

${ }^{5}$ Asres Adimi, supra note 3, p. 181.

${ }^{6}$ IBRD/IMF (2005), Financial Sector Assessment: A Handbook, p. 171. 
institutions that regulate the banking sector. However, the nature and purpose of their regulation often varies from the nature and purpose for which banks are regulated.

Although the financial sector is regulated for a variety of purposes, the regulatory objective that distinguishes financial sector regulation from other business regulations is generally prudential regulation which aims at protecting the financial sector from systemic risks. In order to effectively meet its desired objectives, financial sector regulation should (i) be developed on clear legal basis; (ii) be proportionate in terms of the risks it aims to avert and the barriers it places in the way of doing business; (iii) encourage true competition; and (iv) it should be based on fairness and equity. This in turn requires an understanding of the nature of the various financial sector actors, and the extent to which each of these actors pose systemic risks to the financial sector and the economy as a whole. Duplication of regulatory standards designed for the banking sector (that poses greater systemic risks) for the non-banking sector may discourage potential entrants and drive out existing ones thereby threatening the existence of NBFI sectors.

Equipment financing business which was an unregulated sector two decades before has been placed under tight NBE regulation which seems to be modeled from the banking regulation. Based on its mandate under Proclamation No. 807/2013, the NBE has enacted several directives on regulation of the business of financial leasing. An examination of the Proclamation and the directives issued by the NBE triggers several questions, inter alia, the characterization of equipment leasing business, the nature and propriety of the current regulation by the National Bank of Ethiopia (NBE), and the distinction between financial leasing companies and other financial companies from the regulatory perspective. This article deals with these issues and outlines the regulatory challenges in the regulation of financial leasing sector in Ethiopia with the view to underlining the need for reform.

This research involves analysis of legislation, directives, manuals, forms, model documents and letters issued by the NBE in relation to equipment financing. There are seven major directives stated in Section 3.1 that the NBE has enacted in implementing its regulatory mandate. This article examines these seven directives in light of basic principles of regulatory quality. In addition to these directives which are the fundamental instruments of NBE regulation, the article also examines the Capital Goods Lease Business Proclamation No. 807/2013 and other manuals, letters and guidelines issued by the NBE in relation to the sector.

Examining the effectiveness of a regulatory system is inquiring into the regulatory framework, its fairness, its impacts both positive and negative and its 
internal and external consistency with established economic and political values. ${ }^{7}$ Evaluating regulatory effectiveness is more often done ex ante before enactment of the regulation by way of consultations and regulatory impact analysis (RIA). Ex post evaluation is less developed than ex ante evaluation which uses sophisticated tools of regulatory impact analysis (RIA). In this regard various authorities indicate that experiences vary considerably from country to country and from industry to industry even within a country. ${ }^{8}$ In terms of methodology, even most OECD countries are 'yet to establish a sophisticated methodology and quality control of ex post evaluations of regulations. ${ }^{9}$ Therefore, in the absence of standardized methodology and indicators for ex post review of regulations, this author has adapted qualitative indicators for this inquiry from OECD's eight indicators of regulatory performance and regulatory policy evaluation. ${ }^{10}$

Ex ante cost-effectiveness and net benefit efficiency indicators as well as ex post economic indicators are excluded from this analysis. Cost efficiency evaluation in terms of compliance cost for businesses and administrative cost for the regulator could not be done, because the regulations have not been fully implemented for lack of an empowered private sector. This article therefore uses the following five principle-based indicators:

a) Process/procedural legitimacy- this looks at the procedure followed in enacting the directives

b) Internal consistency- this looks at consistency of the directives, i.e., the extent of congruence between the enabling proclamations and the directives

c) Consistency with other values - the scope and nature of the directives vis-à-vis the other values mainly competition and consumer protection principles

d) Equity/Distributional fairness/substantive validity/- this looks at the content of the directives and the regulatory burden imposed on the regulated sector

e) Outcome and impact effectiveness - this looks at the extent to which the regulation produced the intended results in terms of intermediate outcomes.

\footnotetext{
${ }^{7}$ Cary Coglianese (2012), Measuring Regulatory Performance: Evaluating the Impact of Regulations and Regulatory Policy, Organization for Economic Cooperation and Development (OECD), Expert Paper No. 1, August 2012, p. 8.

${ }^{8}$ Organization for Economic Cooperation and Development, Regulatory Policy Outlook (OECD, 2015), p. 129.

${ }^{9}$ Id., 128.

${ }^{10}$ Coglianese, supra note 7 , pp. 18, 34 .
} 
These principles-based parameters can fairly reflect the quality of the regulation of equipment financing sector in Ethiopia. Nevertheless there still remains some degree of incompleteness since an analysis of administrative cost and compliance cost are not included. This requires solid empirical data which in turn require a robust equipment financing business in the country. I argue that, a robust equipment financing sector cannot come into existence unless the current regulatory framework is improved. In spite of the absence of cost-benefit analysis, the findings of this article can contribute as an input for policy making and further research in the field. This research does not address operating leases regulated by the Ministry of Trade.

\section{Theoretical Underpinnings of Financial Leasing Regulation in Ethiopia}

\subsection{Leasing versus bank loan}

Financial leasing is one of the alternative mechanisms of solving financing needs of businesses and individuals. It combines the attributes of lending and leasing, hence the name financial leasing or lease financing. But in simpler terms it can be taken to mean lending equipment instead of lending the funds needed to purchase it with the possibility of eventual ownership of it by the borrower. In spite of these parallels between financial leasing and bank lending, there are notable differences. Although the equipment leased in financial leasing serves an equivalent purpose with collateral in bank lending, it is owned by the lessor, not by the lessee. This stands in marked contrast with collateral which is owned by the borrower. Hence, unlike banks that have to go through bureaucratic foreclosure procedures ${ }^{11}$ when the borrower defaults, lessors can simply take back the leased equipment without much difficulty in case of lessee default. ${ }^{12}$ On the other hand, while banks have to charge interest on their loans, lessors are not necessarily required to charge interest, as they can simply charge the installment payments with premiums added on as service charge.

${ }^{11}$ The old judicial foreclosure pursuant to the Civil Procedure Code has been replaced by power of sale foreclosure by virtue of the Foreclosure Proclamation, i.e., Proclamation to Provide for Property Mortgaged or Pledged with Banks, Proclamation No. 97/1998, Federal Negarit Gazeta, No.16, 19th, February 1998. While the Proclamation eliminates the requirement of judicial oversight of the foreclosure, it does not completely rule out the applicability of the Civil Procedure Code provisions to regulate the auction process to be run by the lender- See Article 6. The same applies with business mortgage, See Business Mortgage Proclamation No.98/1998, Federal Negarit Gazeta, No.16, 19th, February 1998, Article 16.

${ }^{12}$ See Article 6(2) of Capital Goods Leasing Business Proclamation No. 103/1998 which authorizes the lessor to simply take back the asset leased upon giving 30 days' notice. 
The similarity of leasing and borrowing is even more manifest from the demand side. In financial economics, lease and debt are so similar that they are assumed by some writers to be substitutes. ${ }^{13}$ The more a firm leases, the lesser it borrows or vice versa. Firms, especially Small and Medium Enterprises (SMEs) evaluate buying equipment through borrowing funds with lease financing of the same equipment. 'When a firm buys an asset, it obtains both the right to the services of that asset over the period it is owned plus the right to sell the asset at any future date. With a lease, the firm acquires only the right to the asset's services for a period specified in the contract' with the possibility of owning it at the end. ${ }^{14}$ However, purchasing equipment requires huge upfront investment in contrast to leasing which can enable a firm to acquire an asset by investing a fraction of its value upfront. That is the main reason why financial leasing is associated with SMEs, startups and other small enterprises.

Lease financing is thus meant to enable hundreds of thousands of youth with skills and good project ideas, small businesses and SMEs that cannot afford to borrow from banks to acquire capital assets. The potential benefits to the overall economy from the well-functioning leasing business is huge that lease financing constitutes an important part of financing in many other countries.

\subsection{The Evolution of the Law of Equipment Lease Financing in Ethiopia}

The history of lease financing can be traced back to a very distant past. According to one account, "leasing of equipment has been in practice since the ancient times in the Sumerian City of Ur, about 2010 BC which was then a major commercial center. It involved the rental of farm tools leased to farmers by priests who then stood as government authorities." 15 Moreover, Hammurabi's Code (1750 BC), "acknowledged the existence of lease of movable property." 16 Ethiopia's experience with leasing also goes some centuries back. For instance, the relationship between lessor and lessee was regulated by the Fetha Nagast, which was in force since the mid- $15^{\text {th }}$ century. ${ }^{17}$

The 1960 Civil Code has introduced modern leasing to Ethiopia. The Civil Code set out a fairly modernized legal platform for the exercise of equipment

${ }^{13}$ James Ang and Pamela P. Peterson (1984), 'The Leasing Puzzle,' The Journal of Finance, 39, pp. 1055-1065.

${ }^{14}$ Clifford W. Smith and Macdonald Wakeman (1985), 'Determinants of Corporate Leasing Policy,' The Journal of Finance, 40 no 3, pp. 895-908.

${ }^{15}$ Iyare Otabor-Olubor (2017), The Next Frontiers for Finance Leasing in Sub-Saharan Africa: Revisiting Secured Transaction Law in Nigeria, (Vienna, UNCTAD), p. 4.

${ }^{16}$ Ibid.

${ }^{17}$ Peter L. Strauss, ed. (1968), The Fetha Nagast: The Law of Kings, Translated from Ge'ez by Aba Paulos TzAdua, (Addis Ababa: HSIU Faculty of Law) 199-206 ; Civil Code of the Empire of Ethiopia, Negarit Gazzeta Special Edition (1960). 
financing business with varieties of types of contracts. These include sale with ownership reserved (Articles 2387-2389), sale with right of redemption (Article 2390-2393), Hiring sale/ hire purchase/ (Articles 2412-2415) and letting and hiring (Articles 2727-2738) ${ }^{18}$ According to Article 2387(1) sale with ownership reserved is a contract whereby possession of a thing is transferred to a buyer with the ownership reserved with the seller until price is paid. Risk is transferred to buyer upon delivery. On the other hand, sale with right of redemption is an arrangement of financing in which a seller reserves the right to redeem the thing sold within a maximum of two years from date of sale. ${ }^{19}$

A hire-purchase contract in the Civil Code is more of an installment sale. However, this provision does not explicitly provide the most important features of a hire-purchase contract which is the joint ownership of the equipment during the term of the contract. In hire-purchase, the important feature is that with each payment of the instalment, an equal percentage of ownership of the asset is transferred to the buyer implying that from beginning to end of the payment, the thing is jointly owned by the seller and buyer ${ }^{20}$ Letting and hiring refers to the contract commonly known as operating lease in modern parlance. Operating lease is defined under Article 2(5) of Proclamation No. 103/1998 as an agreement in which a person lets another to use his equipment in return for a payment for a maximum period of two years. There is no issue of transfer of ownership in an operating lease unlike in a financial lease or hire-purchase.

All these contracts have elements of easing financial burden of acquiring an asset needed by a business or a consumer. However, the Civil Code does not have the more modern types of contracts such as lease financing and sale and lease back transactions. On the other hand, all these provisions in the Civil Code with the exception of those on letting and hiring were very scanty, and were thus inadequate to define the nature of the contracts, and the respective rights and obligations of parties to these contracts. This seems to have contributed negatively towards the development of the equipment financing industry in Ethiopia.

Financial leasing is essentially a capital intensive investment as opposed to operating leases. This is because an investor can buy equipment and run an operating lease business with that equipment. In contrast, such an enterprise makes little business sense in financial leasing as the lease being for long duration (often for the full economic life of the equipment), the leasing business will be practically idle except for collecting rents by just leasing the sole

\footnotetext{
${ }^{18}$ An interesting discussion on the relationship of these types of contracts from the perspective of secured transactions law is made by Asres Adimi, 'Rethinking Ethiopian Secured Transactions Law,' supra note 3, 181-182.

${ }^{19}$ Civil Code of the Empire of Ethiopia, Articles 2390-2391.

${ }^{20}$ See Article 2(4) of Capital Goods Leasing Business Proclamation No. 103/1998.
} 
equipment. This explains the reason why there are so many operating lease businesses, but practically no financial leasing ones with the exception of those created by the government. ${ }^{21}$

A separate proclamation was enacted to facilitate lease financing as an alternative to traditional financing mechanisms with the view to support growth of the Micro and Small Enterprises (MSE) sector in 1998. The enactment of the Capital Goods Leasing Business Proclamation No. 103/1998 ${ }^{22}$ has a similar rationale. The Proclamation clearly outlined the three conventional types of lease contract models, namely operational lease, finance lease and hire-purchase contracts. Article 2(3) defines financial lease as a type of leasing by which a lessor provides a lessee against payment of mutually agreed instalments over a specified period with the use of specified capital goods. The Proclamation goes further in explaining the leased assets as: (a) either already acquired by the lessor; or (b) purchased by the lessor from a third party, known as the supplier, chosen and specified by the lessee.

Under a contract of financial lease, the lessor retains full ownership right on the capital goods during the period of the lease agreement, and, subject to agreement between the two parties, the lessee may have an option to purchase the capital good outright after the termination of the lease period at an agreed price. On the other hand, hire-purchase is defined as a contract by which a lessor provides a lessee with the use of specified capital goods, against payment of mutually agreed instalments over a specified period, under which, with each lease payment, an equal percentage of the ownership is transferred to the lessee and, upon effecting of the last payment, the ownership of the capital goods is automatically transferred to the lessee.

The basic difference between the two types of contracts is apparent: in lease finance, the ownership of the leased asset remains with the lessor, whereas in hire-purchase, ownership is progressively transferred to the lessee from the lessor in proportion to the instalments paid. Hence, while in hire-purchase

${ }^{21}$ The motivation behind the establishment of these so-called five big regional state owned CGFB companies was purely political. And, as such most of them have not yet been successful from the business perspective. See generally Robert Homans (2018), Turnkey Projects' Current Status Assessment, 9.

${ }^{22}$ See the Preamble of Capital Goods Leasing Business Proclamation No. 103/1998. The preamble reads as follows: "Whereas, for those investors who have the desire, knowledge and profession to participate in various investment activities but could not act due to lack of capital, it is necessary to create an enabling environment for the establishment of an alternative source of financing; Whereas, it is believed that lessors of capital goods can fill the existing gap which is not addressed by the existing financial institutions; Whereas, the existing laws concerning capital goods leasing business are found incomplete ..." 
payment of the last instalment signals transfer of ownership, the same cannot be said with regard to lease-finance unless specifically agreed between the lessor and lessee. In contrast, operational lease is a short term lease. It is less of a financing instrument than the two because it does not in any way lead to the eventual transfer of ownership of the leased asset to the lessee.

However, the introduction of financial leasing through Proclamation No. 103/1998 did not stimulate the equipment financing sector as intended. During the fifteen years after its enactment, it did not enable the emergence a single equipment financing company. This led to the enactment of the Capital Goods Leasing Business (Amendment) Proclamation No. 807/2013. As if lack of regulatory supervision was the cause for disinterest of the private sector in equipment financing, the amendment placed the sector under the regulation of the National Bank of Ethiopia. Hence, the amended proclamation introduced a clear institutional separation between financial leasing and operational leasing in that, while the former was placed under the regulatory supervision of the NBE, the later remained within the general licensing requirement of Ministry of Trade.

Secondly, the Proclamation also introduced portfolio separation in such a way that financial leasing company cannot do operational lease and vice versa. In effect the same company cannot do operational and equipment leasing business simultaneously. The amendment has also introduced important reforms such as registration requirement for equipment finance agreements ${ }^{23}$, and exemption of VAT on payments made to the lessor under such contracts.

In spite of these changes, no independent leasing company or captive leasing company (as defined under Section 2.3 below) has emerged during the last five years from the private sector partly due to the high equity capital requirement and other technical entry barriers. This led to the elimination of the ban on foreign investors from the sector which in turn brought some interest from foreign firms. Nevertheless the excessive regulatory requirements seem to hamper the private sector's enthusiasm. ${ }^{24}$ On the other hand, the Addis Ababa City Administration and the four big regional state governments have each

\footnotetext{
${ }^{23}$ The Council of Ministers has afterwards issued Registration and Supervision of Capital Goods and Capital Goods Leasing Agreements Council of Ministers' Regulation No. 309/2017, Negarit Gazeta, $20^{\text {th }}$ Year, No. 40, July 2014 on registration of Lease Finance Agreements. This regulation is aimed to resolve the hitherto problem emanating from absence of registration of assets submitted as collateral. With such registration, the problem of establishing validity and seniority of security claims is expected to be streamlined.

${ }^{24}$ As of August 2019 the first private sector financial leasing company has been licensed. See Kaleyesus Bekele, 'Capital Lease Company Opens Shop' The Reporter, August 10, $2019<\mathrm{https}: / / \mathrm{www}$.thereporterethiopia.com/article/capital-lease-finance-company-opensshop>
} 
established equipment finance companies. ${ }^{25}$ Microfinance institutions are also authorized to provide a similar service. ${ }^{26}$ With the inclusion of Development Bank of Ethiopia that gives equipment lease financing for the value between Birr 1 million to 30 million, the equipment leasing landscape is currently heavily dominated by the public sector.

\subsection{Types of equipment financing businesses}

Generally, equipment financing business can be operated by three types of companies which are often referred to as banks, captives, and independents. Banks when allowed to operate equipment financing business do leasing activity primarily to collect interest payment from the lessees in addition to the value of the equipment. Captive leasing companies, i.e., companies which are subsidiaries of equipment manufacturers, do leasing business in order to boost sales of their parent company by offering to customers easy payment solutions. On the other hand, independents are companies affiliated to neither banks nor equipment manufacturers.

\subsubsection{Banks or bank subsidiaries}

In many countries banks provide equipment leasing as one of their financial products. By using the huge funds under their custody, banks can have lesser cost in acquiring the equipment needed for leasing. According to Kieso D. et al, relying on their competitive advantage, banks in the USA have entered the equipment leasing market aggressively in response to the increasing demand from the market. As a result, some big banks like Credit Suisse, Chase, Barclays and Duetsche Bank have sizable leasing subsidiaries. ${ }^{27}$

This is in spite of the implementation of Basel II and III accords which together aim to discourage banks from engaging in leasing, as the associated "assets" are heavily discounted for the purpose of the various capitalization ratios, i.e. leasing comes with a relatively high cost of capital for banks. The Basel accords have thus made most banks to shift their equipment financing businesses to subsidiaries or transferred them to independents in exchange for small equity. And when banks have an equity interest in these companies, it is considered a 'non-banking' equity interest; but since such leasing companies tend to be very thinly capitalized, the impact on the bank's equity ratio is insignificant. ${ }^{28}$ However, in spite of the continued tightening of regulation in the

${ }^{25}$ Robert Homans, supra note 21.

${ }^{26}$ Capital Goods Leasing Business (Amendment) Proclamation No. 807/2013, Article 4(2)

${ }^{27}$ Kieso D. et al, (2011), Intermediate Accounting Vol. II, (United States of America: John Wiley and Sons), 1121.

${ }^{28}$ Equipment Leasing \& Finance Foundation (2006), Rise of the Banks in Equipment Finance: Establishing a Sustainable Engine for Growth, p. 43. 
banking sector which was expected to discourage banks from direct involvement of banks in equipment leasing sector, the leasing market in the USA is still heavily dominated by banks. ${ }^{29}$

\subsubsection{Captive companies}

A captive finance company is an entity whose primary mission is to provide financial products that promote and facilitate the sale or lease of products manufactured by its parent company. ${ }^{30}$ Captive equipment leasing companies often operate as subsidiaries of equipment manufacturers. Some of the wellknown captive financial leasing companies include Caterpillar Financial Services Corporation, Ford Motor Credit Company, Boeing Capital Corporation, Deere \& Company, Nissan Motor Acceptance Corporation, American Honda Finance Corporation, Toyota Financial Services, and Volvo Financial Services.

Although direct sale remains the most reliable marketing mechanism, using a leasing subsidiary is becoming increasingly a common practice. Compared to banks/bank affiliates and independents, captives have the advantage of product knowledge and easier and more predictable supply. ${ }^{31}$ In terms of effectiveness "though captives sometimes generate profit from a financial services perspective, their primary objective is to generate profit for the parent by increasing equipment sales." 32 The lack of flexibility to offer alternative products (other than that of the parent) to consumers is the downside to growth and expansion of captives.

\subsubsection{Independent companies}

Independent lessors are sometimes called third party vendors. Because they lack the low cost funds like banks or the access to equipment and related product knowledge that captives possess, independents are presumed to be disadvantaged from the competitive point of view. ${ }^{33}$ The difference is clear; "banks have access to low cost deposits from which to provide funding. Captives usually have access to efficient parent company treasury operations that offer modestly priced

\footnotetext{
${ }^{29}$ Kieso D. et al, supra note 27, 1121.

${ }^{30}$ Secretariat of the Basel Committee on Banking Supervision Bank for International Settlements, 'Re: Basel Committee on Banking Supervision and Board of the International Organization of Securities Commissions Second Consultative Document Regarding Margin Requirements for Non-Centrally Cleared Derivatives'

<https://www.iosco.org/library/pubdocs/403/pdf/Captive\%20Finance\%20Companies.pdf> (accessed on August 10 2019).

${ }^{31}$ Ibid.

${ }^{32}$ Macquerie Equipment Finance, Reasons to Choose an Independent Lessor, $<$ http://static.macquarie.com/dafiles/Internet/mgl/com/mef/pdf/wp-reasons-to-choose-anindependent-lessor.pdf> (Accessed July 10, 2018).

${ }^{33}$ Ibid.
} 
debt. ${ }^{34}$ However, this does not necessarily mean that independents cannot compete with banks and captives. As they can offer varieties of products as opposed to captives, they meet customer choices much better than captives. The comparatively cumbersome regulatory environment under which banks or bank affiliates operate means that independents can have some advantage against banks or their subsidiaries. ${ }^{35}$

Independents are also found to be more innovative than banks or captives in meeting niche market demands. As one survey conducted on the American equipment financing market found out, "independents can apply expertise to a niche focus, they can market where the banks can't operate or where they can't operate effectively, and they can often adapt more quickly than a bank-owned company. ${ }^{36}$ In the IT equipment market, for instance, independent lessors have succeeded by reselling used equipment in the secondary market at the same time giving customers attractive pricing, terms, and service options on the refurbished equipment -with the customer being the beneficiary. In contrast, "equipment manufacturers (through their captive finance company) tend to steer customers toward their 'latest and greatest' (often a euphemism for 'most expensive') new models." 37

\subsection{Types of financial regulation applicable to the financial leasing Sector}

Generally, financial sector institutions are subject to two broad categories of regulatory supervision. These are commonly known as prudential and nonprudential regulations. Prudential regulation in its turn can be bifurcated into micro-prudential and macro-prudential approaches. Non-prudential regulations include conduct of business regulations, competition regulation, and consumer protection regulation and so on. In this sub-section, an overview of these major types of regulatory activities will be made in the light of financial leasing sector.

Determining the appropriate mix of regulation for various financial sector institutions has always been an intricate task for regulatory authorities. This is because, "while both competition regulation and conduct of business regulation (including market integrity) apply to all sectors and institutions in the financial system, assessing which type of NBFIs warrant prudential regulation is, in practice, a difficult exercise." ${ }^{, 38}$ Since clarity of these regulatory categories and their respective objectives is crucial for developing the appropriate regulatory

\footnotetext{
${ }^{34}$ Michael J. Fleming and David S. Wiener (2011), 'The Place of the Independent Equipment Finance Company,' Journal of Equipment Lease Financing, 29 No.2: 2.

${ }^{35}$ Equipment Leasing \& Finance Foundation, Rise of the Banks in Equipment Finance, 43

${ }^{36}$ Ibid.

${ }^{37}$ See generally, MACQUARIE, Reasons to Choose and Independent Lessor

${ }^{38}$ IBRD/IMF, Financial Sector Assessment, supra note 6, 173.
} 
framework for equipment financing sector, a more elaborate discussion on each type of regulation is necessary.

\subsubsection{Prudential regulation}

According to Carmichael and Pomerleano, prudential regulation is a form of regulation that involves counteracting asymmetric information problems in financial markets. Information asymmetry is said to arise "where products or services are sufficiently complex that other forms of regulation are insufficient." 39 In the banking sector, the purpose of prudential regulation is thus "to minimize information asymmetry problems faced by the large number depositors in monitoring the use of their deposits." ${ }^{40}$ However, this seems rather a narrower conception of prudential regulation, because prudential regulation has much more than the dampening problems emanating from information asymmetry in the financial market.

The broader objective of prudential regulation of the financial sector is maintaining a healthy and stable financial sector. Because, the financial sector (specially the banking sector) of an economy plays a vital role by "facilitating payments, providing liquidity, pooling savings and risk-sharing, and credit intermediation between savers and investors", ${ }^{41}$ instability of the sector can breed instability into the overall economy. Stricter prudential regulation is thus required for banks. Such strict prudential regulations often impose regulatory requirements on minimum capital, capital adequacy, liquidity, large exposures, loan-loss provisions, risk management, governance, reporting, and so on. ${ }^{42}$

Protecting the financial sector from crisis that can actually or potentially result in systemic risk is the basic purpose of prudential regulation. ${ }^{43}$ In the context of banking business, a systemic risk is defined as "the risk of a sudden, unanticipated event that would damage the financial system to such an extent that the economic activity in the wider economy would suffer. Such shocks may originate inside or outside the financial sector. ${ }^{, 44}$ Examples of causes of such crisis may include the unexpected failure of a major player in the market, a

\footnotetext{
${ }^{39}$ IBRD (2004), Leasing: An Under-Utilized Tool in Rural Finance, pp. 13-14.

${ }^{40}$ Ibid.

${ }^{41}$ William R. White (2013), 'The Prudential Regulation of Financial Institutions: Why Regulatory Responses to the Crisis Might Not Prove Sufficient,' SPP Research Papers, 6, no. 33 , p. 2.

${ }^{42}$ Anne Pouchous (2012), 'The Regulation and Supervision of Microfinance: Main Issues and Progress,' International Institute for Sustainable Development <https://www.iisd.org/pdf/2012/regulation_supervision_microfinance.pdf>_(accessed on July 5, 2018 ) 3.

${ }^{43}$ Richard Herring and Anthony Santomero (2000), What is Optimal Financial Regulation, Pennsylvania: The Wharton School, University of Pennsylvania, p. 4.

${ }^{44}$ Ibid.
} 
sudden breakdown in key technological infrastructure at a critical stage of settlements or payments systems, or a political upheaval such as an invasion or imposition of exchange control in a key financial center, and so on. ${ }^{45}$

Two alternative approaches are followed in implementing prudential regulation: these are micro-prudential regulation and macro-prudential regulation. Markus Brunnermeier et al explain the meaning and distinction between the two approaches:

"Micro-prudential regulation concerns itself with the stability of each individual institution. Macro-prudential regulation concerns itself with the stability of the financial system as a whole. Micro-prudential regulation examines the responses of an individual bank to exogenous risks. By construction it does not incorporate endogenous risk." ${ }^{~} 46$

In other words, micro-prudential regulation "focuses on the health of individual institutions, essentially assuming that, if each institution is healthy, the system will be healthy." 47 In contrast, "macro-prudential approach to prudential regulation rather focuses on the stability of the financial system as a whole, and has both a static (cross-sectional) and a dynamic (time varying) dimension. $" 48$

There are overlaps and vagueness in the relationship between the two. Some institutions are too important (too big to fail) that they warrant individual regulation or supervision as their firm level failure can cause systemic crisis. The regulatory approach for these types of actors can be as much macroprudential as it is micro. On the contrary, the failure of other financial institutions can affect the financial sector only when these institutions fail as a herd. In such situations micro-prudential regulation aims to prevent failure from happening, and the macro-prudential regulation aims at reducing the economic cost of such failure to the sector or the sub-sector as a whole.

This means that not all financial sector actors warrant the same level of prudential supervision. Among financial institutions, it is banks that require the highest standard of prudential regulation. This is because, unlike other firms, "banks use their liabilities as money, so the purpose of regulation in this case is

\footnotetext{
${ }^{45}$ Ibid.

${ }^{46}$ Markus Brunnermeier et al, The Fundamental Principles of Financial Regulation: Geneva Report on the World Economy(Geneva: Center for Economic Policy Research, 2009) xvi

${ }^{47}$ White, supra note 41 , p. 10.

${ }^{48}$ Ibid.
} 
to ensure that bank's assets retain sufficient liquidity to meet any reduction in redeposit, and to discourage any reduction in the first place." 49

When banks lend, they are "betting that the individuals and companies to whom they lend capital will earn enough money to pay back their loans" plus interest; and the banks in their turn will be able to repay deposits plus interest. Eventually, "this process leads to generation of risk and in turn necessitates (prudential) regulation." ${ }^{\text {50 }}$ Therefore, the critical role banks play in intermediation, liquidity provision, and monitoring and information provision means that their failure can lead to systemic crisis and substantial social costs. On top of this, the highly interconnected nature and potential exposure to runs makes banks particularly vulnerable to any kind of actual or perceived failure. ${ }^{51}$

As has been indicated above, besides banks, other financial institutions can also be subject to prudential regulation, albeit at different standards. According to IBRD/IMF Handbook on Financial Sector Assessment, three attributes of financial sector firms must be taken into account for determining the scope of prudential regulation: "(a) the difficulty of honoring contractual obligations; (b) the difficulty faced by the consumer in assessing the creditworthiness or soundness of the institution, and (c) the adversity caused by a breach of contractual obligations. ${ }^{, 52}$ Based on these parameters the prevailing view is that "financial institutions that do not have deposit-like liabilities to the general public do not need to be regulated and supervised as closely as those that do. 53

The most crucial issue here is whether the business of equipment financing justifies prudential regulation. On this point, the prevailing regulatory practice is to subject companies that collect "public deposits to prudential regulation because of the information asymmetry problems faced by the large number depositors in monitoring the use of their deposits. By this rationale, lessors that do not obtain public deposits ... should not be subject to prudential regulation." ${ }^{, 54}$ Evidence from the experience of countries, including developed leasing markets such as US, UK, and Germany and emerging markets such as South Korea and Thailand, show that independent equipment financing companies are not subject to any prudential regulation. ${ }^{55}$ Countries that apply prudential regulation to equipment financing companies similar to the one applied to banks

\footnotetext{
${ }^{49}$ Pushpkant Shakdwipee and Masuma Mehta (2017), 'From Basel I to Basel II to Basel III,' International Journal of New Technology and Research, 3, No. 1, p. 66.

${ }^{50}$ Ibid.

${ }^{51}$ Ibid.

${ }^{52}$ IBRD/IMF, supra note 6, p. 173.

${ }^{53}$ Id., 176.

${ }^{54}$ IBRD, supra note 39, p. 14.

${ }^{55}$ Ibid.
} 
do so when the leasing companies are bank affiliated. ${ }^{56}$ It thus naturally follows that in some countries independent leasing companies are not even subjected to regulation by banking authorities. ${ }^{57}$

From another point of view, it has been suggested that strict prudential supervision is necessary for institutions that are systemically important or institutions that pose systemic risk. Systemic risk is defined as the "risk that an event will trigger a loss of economic value or confidence in a substantial segment of the financial system that is serious enough to have significant adverse effects on the real economy with a high probability." ${ }^{, 58}$ It should be noted that, "economic shocks become systemic because of the existence of spillover effects, whereby there is a contagious loss of confidence that spreads throughout the financial system. Thus, the failure of one financial institution, even a large one, which does not spread to other institutions and the real economy, is not a systemic event." ${ }^{\text {59 }}$

On the other hand systemically risky institutions are not banks only although banks stand out to be the typical ones. To this effect, "systemic risk goes beyond the traditional view of single banks vulnerability to depositor runs. At the heart of the concept is the notion of contagion, a particularly strong propagation of failures from one institution, market or system to another." ${ }^{, 00}$ David Cummins and Mary Weiss identify three primary indicators of systemic importance of an institution: Namely, size, interconnectedness and lack of substitutability of services. ${ }^{61}$

Size of an institution refers to not only whether or not it is 'too big to fail' in the ordinary sense of size of assets or equity held by a firm, but it also includes "the value of derivatives and off-balance sheet (OBS) exposures of the institution and the volume of transactions it possesses." ${ }^{\prime \prime 2}$ Interconnectedness, on the other hand, "measures the extent to which financial distress at one or a few institutions increases the probability of financial distress at other institutions because of the network of financial claims and other interrelation." ${ }^{\prime 63}$ The third

\footnotetext{
${ }^{56}$ IBRD/IMF, supra note 6, 180.

${ }^{57}$ Fleming and Wiener supra note 34, p. 2.

${ }^{58}$ David Cummins and Mary A. Weiss (2014), 'Systemic Risk and the U.S. Insurance Sector', The Journal of Risk and Insurance, Volume 81, No. 3, p. 490.

${ }^{59}$ Id., 492.

${ }^{60}$ De Bandt, and P. Hartmann (2000), 'Systemic Risk: A Survey, European Central Bank': Working Paper Series, European Central Bank, Working Paper No. 35, (Frankfurt, Germany, 8, <https://core.ac.uk/download/pdf/6627784.pdf> (accessed on 2 August 2019)

${ }^{61}$ Cummins and Weiss, supra note 58, p. 493.

${ }^{62}$ Id., p. 494.

${ }^{63}$ Ibid.
} 
indicator, i.e., substitutability "is defined as the extent to which other institutions or segments of the financial system can provide the same services that were provided by the failed institution(s)." ${ }^{64}$ Hence, "in order for lack of substitutability to pose a systemic problem the services in question must be of critical importance to the functioning of other institutions or the financial system" such as the sudden failure of interbank payment or settlement systems. ${ }^{65}$

However, from the indicators of systemic risk of size, interconnectedness and substitutability there is no ground to suggest that financial leasing sector in Ethiopia warrants strict prudential supervision. This is so mainly because the sector is not affiliated to the banks, with the exception of MFIs which are already subject to detailed prudential regulatory requirements. The evidence from experience of other countries such as South Korea, Thailand, UK, Germany and USA suggests that financial leasing companies not affiliated to banks are not subject to prudential supervision. ${ }^{66}$ It is thus safe to conclude that the financial leasing sector should not be subjected to regulatory supervision same as that for banks.

Cumbersome and repressive regulatory regime can retard the growth of the equipment leasing sector. ${ }^{67}$ Such disadvantages include: suppressing growth of the industry by applying unnecessarily stricter prudential standards (for example, by preventing entry of firms because of high capital requirements or causing inefficient use of funds because of the high levels of reserves required and low leverage ratios); impeding the evolution of the sector "from just being a simple substitute for loans to a specialized products serving a natural market for such services" especially SME clients perceived as high-risk clients. ${ }^{68}$ Hence,

\footnotetext{
${ }^{64}$ Ibid.

${ }^{65}$ Cummins and Weiss, supra note 58, p. 495.

${ }^{66}$ Marijan Nemet, 'The New Supervisory Requirements for Leasing Companies in Europe' $<$ http://www.leaseurope.org/uploads/documents/articles-interviews/Marijan\%20NemetDecember2008.pdf> accessed 1 August 2019; In the USA prudential supervision applies to banks alone, since the reform to permit banks to engage in financial leasing business in 1977. See Comptroller's Handbook: Lease Financing, Version 1.2,2017, <https://www.occ.treas.gov/publications/publications-by-type/comptrollershandbook/lease-financing/pub-ch-lease-financing.pdf> p. 1-2, accessed 25 July 2019; Opinion of the European Central Bank, 19 October 2015 on the regulation of financial leasing and financial leasing companies' activities (CON/2015/37) <https://www.ecb.europa.eu/ecb/legal/pdf/en_con_2015_37_f_sign.pdf > on the other hand 'U.S. regulations recognize that captive finance companies are not financial entities and are not systemically important' See, Secretariat of the Basel Committee on Banking Supervision, 3;IBRD, Leasing: An Under-Utilized Tool, 14.

${ }^{67}$ IBRD/IMF, supra note 6, p. 173.

${ }^{68}$ IBRD, supra note 39, p. 27.
} 
the question is not whether financial leasing should be regulated by institutions that regulate banks. The issue is tailoring regulatory standards for non-bank financial leasing sector that is distinct from regulations applying to banks. Indeed, in most jurisdictions the same institutions that regulate banks also regulate financial leasing. This may be because banks are mostly allowed to do financial leasing as an alternative product; or it may be due to the fear of regulatory arbitrage. ${ }^{69}$

\subsubsection{Competition and consumer protection regulation}

In addition to prudential regulation, financial sector firms including equipment financing businesses may be subjected to non-prudential regulations such as competition regulation, consumer protection regulation, and other types of regulation. The objectives of these regulatory interventions are diverse such as protection of consumers, efficiency enhancement, and other broader social objectives such as supporting the growth of a particular sector-SME, export sector, manufacturing sector or housing. ${ }^{70}$ Competition regulation works for the benefit of consumers (by optimizing quality and fair price) and for efficiency enhancement objectives resulting from the competition. Regulation of lending and loan collection practices, loan pricing and lending interest ceilings are provided with the objective of consumer protection. ${ }^{71}$

However, using financial sector regulations for social policy objectives is not free from controversies. Governments are often tempted to exploit financial sector regulation to achieve purposes far removed from the objectives of preventing systemic risk, or protecting consumers or increasing efficiency in the sector. Good examples of such policies include creating regulatory privileges for institutions that provide financing for priority sectors such as housing, government guarantee schemes for loans given to favored sectors, allowing favorable interest rates for financial institutions giving loans to preferred sectors, etc. ${ }^{72}$ Government subsidies for financing to the export sector is also another example. ${ }^{73}$

However, not all of these regulations necessarily meet their objectives. Interest caps on lending for non-bank financial sectors, for example, are aimed

\footnotetext{
${ }^{69}$ Pierre Boyer and Hubert Kempf (2006), 'Regulatory Arbitrage and the Efficiency of Banking Regulation,' CESifo Area Conference on Applied Macroeconomics, Munic Based, Globe Spanning Economic Research and Policy Advice Institution, 18-19 March 2016 <https://www.cesifo-group.de > docs > am16_Gollier > Papers > am16_Boyer> (accessed on 10 August 2019).

${ }^{70}$ Fleming and Wiener, supra note 34, p. 3.

${ }^{71}$ Anne Pouchous, supra note 42, p. 9.

${ }^{72}$ Id., 11.

${ }^{73}$ Ibid.
} 
to avoid abusive interest rates. However, experience from the MFIs shows that policy makers are often unable to set an interest rate cap high enough to permit development of sustainable MFI sector. ${ }^{74}$ Likewise, "conduct of business regulation serves the objective of protecting clients from harm. Because its focus is 'client-facing', it does not encompass 'firm-facing' regulations such as the imposition of general supervision obligations, record keeping requirements, or net capital requirements." 75

These non-prudential regulations may sometimes overlap and at other times contradict with prudential regulation which primarily aims at preventing or minimizing systemic risks. On the other hand, researches have shown that a number of these regulatory interventions such as "restrictions on product lines, are ineffectual at best in safeguarding against systemic risk and may weaken regulated institutions by preventing them from meeting the changing needs of their customers." ${ }^{, 76}$ Similarly, the "fit and proper test' requirement aimed at achieving safety and soundness may prove to be an entry barrier contradicting the efficiency gains from competition. ${ }^{77}$

There can also be overlaps in various types of regulatory mechanisms and objectives rendering some of the non-prudential regulations unnecessary in the peculiar context of the financial sector. Prudential regulation intended at dampening information asymmetry problem that prevents consumers from identifying the best institution can minimize the problem through an ex ante fit and proper test. Likewise ex post disclosure requirements can achieve the same objective by eliminating the information symmetry challenges in favor of consumers. $^{78}$ Thus, if properly applied, these regulatory instruments can enhance consumer protection and efficiency enhancement objectives. ${ }^{79}$

\section{The Regulatory Landscape of Financial Leasing Sector in Ethiopia}

This section deals with the regulatory environment of financial leasing in Ethiopia. As stated in Section 1, the seven directives issued by the NBE are examined in light of five indicators, namely: process/procedural legitimacy, internal consistency, consistency with other values, equity/distributional fairness (substantive validity) and outcome and impact effectiveness.

\footnotetext{
${ }^{74}$ Id., 4.

${ }^{75}$ Niamh Moloney, et al (eds) 2015, The Oxford Handbook of Financial Regulation, (London: Oxford University Press), p. 538.

${ }^{76}$ Id., 4.

${ }^{77}$ Ibid.

${ }^{78}$ Id., 7.

${ }^{79}$ Id., 4.
} 


\subsection{Procedural legitimacy}

One of the most prominent mechanisms of ensuring procedural legitimacy of regulations is consultation with stakeholders. In the context of business regulations, the stakeholders are the businesses which the regulation aims to govern. "Consultation with businesses and the public is integral to improving the quality of regulation" since regulatory proposals which are "informed by public consultation are ... more likely to be efficient and effective and less prone to the risk of regulatory failure. ${ }^{, 80}$ In addition to enhancing the quality of regulations, consultation also promotes transparency and builds trust between the regulator and the regulated thereby improving compliance with regulations ${ }^{81}$ Consultation is also important to assess the potential impact of a regulation though regulatory impact analysis which should be done apart from consultations.

So far, the NBE has issued seven directives. namely: Minimum Paid up Capital Requirements Directive, ${ }^{82}$ Requirements for Licensing Directive, Manner of Financial and Operational Information Reporting Directive, Capital Adequacy Ratio Requirement Directive, Limit of Exposure to a Single Lease Directive, ${ }^{83}$ Operational Modality Directive, and Penalty for Failure to Comply with Regulatory Requirements Directive.

${ }^{80}$ Organization for Economic Cooperation and Development, April 2008 Policy Brief:

Measuring Regulatory Quality, 4

(2008)<https://www.oecd.org/regreform/Policy\%20Brief\%20-

$\% 20$ Measuring\%20Regulatory\%20Quality.pdf > (accessed on 10 July 2018)

${ }^{81}$ Ibid.

${ }^{82}$ The initial directive issued in 2013, i.e., Minimum Paid up Capital Requirement Directive No. CGFB 01/2013 required 200,000,000 Birr as the minimum capital for all equipment financing companies across the board. However, this was revised by the directive presently in force, i.e., Minimum Paid up Capital Requirement Directive No. CGFB/07/2017 ( $2^{\text {nd }}$ Replacement $)$ in 2017. The new directive bifurcated the minimum capital requirement into two: 200,000,000 for those businesses targeting Micro and Small Enterprises (MSE); and 400000000 Birr for those targeting Small and Medium Enterprises (SME) and large businesses.

${ }^{83}$ The initial directive issued in 2016, i.e., Limit on Capital Goods Finance Exposure to a Single Lessee, Directive No. CGFB/05/2016 imposed birr 1million as the maximum limit of exposure towards a single customer. This was replaced by Directive No. CGFB/08/2017 (Second Replacement) in 2017. Obviously, following the bifurcation of the minimum capital requirement and the market into two exclusive categories, the exposure limit directive was amended introducing a new Limit 30000000 for those targeting the SME market. The exposure limit of those serving micro and small businesses remained at 1 million Birr. However, the exposure limit directive was revised for the second time by Limit on Capital Goods Finance Exposure to a Single Lessee Directive No. CGFB/09/2019 This third replacement introduced a maximum exposure limit of $2.5 \%$ 
Two of the directives, i.e., Minimum Capital Directive and Requirement for Licensing Directive were issued before any of the equipment leasing companies came into existence ruling out any possibility for consultations. ${ }^{84}$ With regard to the other three directives, it is not clear whether or not consultations were made. Even if consultations were ever made, it would not be a meaningful exercise as all the existing companies are effectively regional government owned or controlled policy institutions with no independent business visions apart from the government's objectives in creating them, which is not in any way different from the NBE's vision for them. Thus, these directives lack procedural legitimacy.

The right approach to regulatory development is usually to follow rather than precede the emergence of the regulated sector. This is because regulatory enactments should be gradual and responsive to real problems felt by the sector. Experience from the past development of banking and insurance as well as MFI regulation shows that detailed regulations were developed gradually as responses to practical challenges. This is in line with the legislative intent in the respective proclamations (banking, insurance, MFI as well as CGFB) that give discretionary power to enact directives when needed, instead of obligation to do so ex ante before the emergence of the sector.

Developing an enabling and conducive environment can be achieved better through a sequential and progressive approach than by one-off upfront regulation. For instance, the G20 Financial Inclusion Experts group in the 'Principles for Innovative Financial Inclusion' issued in June 2010 recommends a "test and learn" approach by regulators rather than regulating in advance of market conditions. ${ }^{85}$ Therefore:

'instead of attempting to foresee all possible business models and issue corresponding regulatory measures, regulators should set requirements in a flexible and open manner that can encompass different models in a single range of rules and elaborate as needed further on, rather than inhibiting the development of new products from the outset. ${ }^{86}$

of total capital of companies serving MSE market; and $15 \%$ of total capital for a single SME lease and $25 \%$ of total capital for a single large business(outside the SME definition) lease.

${ }^{84}$ Note that these directives were issued in 2013, whereas the five regional CGFB companies were formed in 2014, See Birritu No. 118, p. 31.

${ }^{85}$ (AFI, 'Policy Note: Mobile financial services Regulatory approaches to enable access', 2010, p.8<https://www.findevgateway.org/sites/default/files/mfg-en-paper-mobilefinancial-services-regulatory-approaches-to-enable-access-nov-2010.pdf $>$ accessed on 1 Sept. 2019).

${ }^{86}$ Ibid. 


\subsection{Internal consistency}

A good regulatory system should be internally consistent in the sense that derivative legislation should not contradict with the parent laws. It should also make a clear demarcation of regulatory power among regulatory institutions whenever more than one oversight body is empowered to regulate a given sector. Proclamation No. 807/2013 vests primary regulatory power over financial leasing companies to the NBE. However, the same Proclamation also recognizes the regulatory jurisdiction of the Ministry of Trade (MOT).

In this regard, what is provided in Article 4, Paragraph 6, Sub-paragraphs 4 and 5 of the Proclamation seem self-contradictory. Sub-paragraph 4 states that "the National Bank of Ethiopia may issue directives that enable it to regulate and supervise the business of capital goods finance in accordance with this Proclamation." Then, sub-paragraph 5 provides that "without prejudice to the provision of sub article (4) of this Article, the Ministry may issue other directives necessary for the implementation of this Proclamation." These provisions do not unequivocally demarcate the division of directive making power between NBE and MOT.

However, a closer scrutiny of the wording of the provision that defines NBE's regulatory power may shed some light on the matter. Article 4(4) of the Proclamation provides an exhaustive list of powers to the NBE to issue directives in respect of the following matters: (a) criteria to be fulfilled to obtain capital goods finance business license; (b) fitness and qualification criteria to be fulfilled by directors and a chief executive officer of a company engaged in capital goods finance business; (c) the amount of capital and reserves to be maintained by a company engaged in capital goods finance business; and (d) provisioning for doubtful accounts and depreciation of fixed assets. ${ }^{87}$ One of the established cannons of legal interpretation is that "the expression of one thing implies the exclusion of the other (expressio unius est exclusio alterius)." ${ }^{" 88}$ If Proclamation No. 807/2013 mentions the four subject matters, and no others; NBE can issue directives only on these four subject matters; and not on other matters.

However, the Proclamation bestows the NBE with further supervisory powers, but not directive making power. To this effect, Article 4(5) of the Proclamation stipulates that "to ensure adequacy of risk management, safety and soundness of capital goods finance business company, NBE may (a) instruct the company to submit periodic reports; (b) examine or cause the examination of the

\footnotetext{
${ }^{87}$ Capital Goods Leasing Business (Amendment) Proclamation No. 807/2013, Article 4(4)

${ }^{88}$ Antonin Scalia and Bryan Garner (2012), Reading Law: The Interpretation of Statutory Texts, (St. Paul MN: Thompson West, p. 69.
} 
company onsite with or without prior notice; (c) suspend or dismiss one or more directors or the chief executive officer of the company; and (d) take any other appropriate corrective measure." This provision implies that NBE can apply micro-prudential regulatory approaches.

From what is provided in Article 4(4) of Proclamation No. 807/2013, no valid legal basis exists for directives on (1) Manner of Financial and Operational Information Reporting, (2) Limit to Exposure to a Single Lease, (3) Operational Modality Directive and (4) Penalty for Failure to Comply with Regulatory Requirements.

The clauses of these directives do not invoke Article 4(4) of Proclamation No. 807/2013 as the source of power for their issuance. This makes a remarkable contrast to the directives on Minimum Paid up Capital Requirements, Requirements for Licensing, and Capital Adequacy Ratio Requirement, which refer to Article 4(4) as the source of NBE's power. If so, on which provisions of the Proclamation do these directives purport to be based? For example, both the Directive on Limit to Exposure to a Single Lease and the Operational Modality Directive refer to Article 18(4) of the Proclamation. And the Directive on Penalty for Failure to Comply with Regulatory Requirements recites Articles 4(5)(d) and 18(4). Likewise, the Directive on Manner of Financial and Operational Information Reporting recites Article 4(4), 4(5)(a) and 18(4). But none of these provisions empower NBE to issue directives on these subjects.

After listing the subject matters on which the NBE can issue directives, the Proclamation lists other subjects on which NBE can do occasional or ad-hoc supervision. Those subjects for occasional supervision are submission of reports, onsite examination of the company, suspending or dismissing one or more directors or the chief executive officer of the company; and taking other appropriate corrective measure (a power rather vague). From the wordings of the provision these matters are not areas on which NBE can enact directives, because had it been so, the Proclamation would not have provided a separate list of matters in Article 4(4) and 4(5).

On the other hand, it is logical to read Sub-Articles 4 and 5 of Article 4 harmoniously because "the provisions of a legal text should be interpreted in a way that renders them compatible, not contradictory with each other." ${ }^{\prime 89}$ Hence, the powers given to the NBE under Article 4(5) to instruct a company are directly related to monitoring compliance with the directives the NBE is empowered to issue under 4(4). For instance, the power to instruct submission of periodic reports under $4(5)$ (a) or the power to examine the company onsite under $4(5)(b)$ seems to link well with compliance with the directives on capital

\footnotetext{
${ }^{89}$ Id., p. 167.
} 
and reserves under 4(4)(c), and directive on provisioning for doubtful accounts and depreciation of assets under 4(4)(c). On the other hand, the power to suspend or dismiss one or more of the directors and CEO under Article 4(5)(c) logically follows from the fitness and qualification criteria directive issued under Article 4(4)(b) specifically or the licensing directive under 4(4)(a) generally. Hence, there is no directive making power for NBE under Article 4(5) of the amended proclamation.

Regarding Article 18(4) of the Proclamation, it is important to read it together with the other provisions of the Proclamation. In the first place, Article 18 is entirely concerned with distributing regulatory mandate to the Council of Ministers, the Ministry of Trade and NBE that are executive organs. Hence, having dealt with the powers of Council of Ministers and MOT in Article 18(13 ), the Article 18(4) of the Proclamation stipulates that "the National Bank may issue directives that enable it to regulate and supervise the business of capital goods finance in accordance with this Proclamation." Here, it can be inferred that the phrase "...in accordance with this Proclamation" refers to the list of matters under Article 4(4). Had the legislator intended to give NBE a regulatory carte-blanche under Article 18, there would be no point in providing Article 4(4) and stipulating distinct wording in Article 4(5). Again, the harmonious legal interpretation rule helps us here.

The scope of NBE's regulatory power over financial leasing sector can also be viewed by comparing the CGFB Proclamation with the Banking Proclamation and Insurance Proclamation. If one makes such a comparison the law maker's intention to limit NBE's power with regard to financial leasing companies becomes manifest. Even though there is only little resemblance between the powers given to the NBE in banking and insurance proclamations, and the list of powers in Proclamation No. 807, the NBE seems to reproduce the directives from these other sectors. Reproducing directives applicable for other financial sectors to equipment financing sectors- directives which are not envisaged in the enabling proclamation- makes the directives lack legitimacy. ${ }^{90}$ In an interview for Birritu Magazine -a periodical publication of the NBE-, the director in charge of overseeing equipment leasing sector stated that the supervision of lease financing companies "would be based on prudential regulations that help ensure the stability and soundness of the financial

\footnotetext{
${ }^{90}$ The tendency of NBE to exercise expansive regulatory authority over equipment financing sector can also be viewed from the model memorandum of association (MOA) and articles of association (AOA) developed by NBE for these companies. These models simply reproduce the models developed for banks and insurance companies with the necessary deletion of references to the term 'bank' and 'insurance'.
} 
institutions in general and leasing sector in particular"91 implying that equipment financing sector is treated in the same way as banks.

Therefore, by enacting directives on (1) Manner of Financial and Operational Information Reporting, (2) Limit to Exposure to a Single Lease, (3) Operational Modality Directive and (4) Penalty for Failure to Comply with Regulatory Requirements, the NBE has overstepped its regulatory boundary set by Proclamation. Hence, the regulatory regime administered by the NBE is inconsistent with the Proclamation.

\subsection{Consistency with other values}

A good business regulatory system should be consistent with other economic sector regulations or values. At best, it should indirectly promote these values; or at least it should not contradict and defeat the realization of such values. Business sector regulations are naturally expected to be consistent with competition and consumer protection principles. ${ }^{92}$

In relation to competition regulation, the financial leasing sector in Ethiopia is rather characterized by unevenness. The Minimum Paid up Capital Directive categorizes financial leasing companies into those targeting micro enterprises, and those targeting SME sector. The minimum capital required for the companies targeting the former is Birr 200 (two hundred) million and for those targeting the latter is Birr 400 (four hundred) million. According to Article 4(3) of the Directive, the above minimum capital requirement does not apply to equipment leasing companies established by regional governments and/or city governments. The intention here is to exclude the big five leasing companies controlled by four regional states and Addis Ababa City Administration..$^{93}$ In a similar fashion, the Directive on Lessor's Exposure Limitation to a Single Lease does not apply to the 'big five' companies creating a favorable playing field for these actors in comparison to their potential private sector competitors. ${ }^{94}$

Operational Modality Directive introduced in 2019 creates restriction for foreign leasing companies in relation to borrowing from domestic banks. Article 6 paragraph 1 states that "a foreign company shall not borrow funds from the domestic financial system in any manner." However, all of the five CGFB companies owned or controlled by regional governments have been heavily

\footnotetext{
${ }^{91}$ Birritu, National Bank of Ethiopia, supra note 4, p. 34

${ }^{92}$ Martin Cihak and Alexander Tieman (2008), 'Quality of Financial Sector Regulation and Supervision Around the World' IMF, Working Paper 08/190/ 7, $18<\mathrm{https} / / /$ www.imf.org/external/pubs/ft/wp/2008/wp08190.pdf $>$ (accessed on July 10 2018)

${ }^{93}$ See Robert Homans, supra note 21.

${ }^{94}$ See Article 5.2.3 of the Limit on Capital Goods Finance Exposure to a Single Lessee, Directive No. CGFB/09/2019 (Third Replacement).
} 
borrowing from the Commercial Bank of Ethiopia. ${ }^{95}$ Hence, regardless of the rationale behind the restriction, its mere existence undoubtedly creates an uneven competition landscape in the sector. As cost of capital is an important factor for the success of equipment financing enterprises, such unequal treatment can render the playing field rather uneven.

Each of these five CGFB companies is controlled by the four big regional states and Addis Ababa City Administration following the experience of the five big microfinance companies. ${ }^{96}$ Accordingly, Addis CGFB serves the market in Addis Ababa, Oromia CGFB serves the market in Oromia region, Kaza CGFB, Walya CGFB and Debub CGFB companies serve respectively the markets in Tigray, Amhara and SNNP regions. ${ }^{97}$ This further limits competition in the sector, and prevents the benefits that would have trickled down towards the consumers as a result of competition. Moreover, the prohibitively high minimum capital threshold for new entrants at 200 million and 400 million, can be a barrier to the entry of new businesses thereby entrenching the uncompetitive market. In a survey conducted by one study in Ethiopia, "a significant number of the respondents $(73.8 \%)$ perceives that the minimum paidup capital is set to be high which may be a barrier for new entrants from the private sector." $" 98$

\subsection{Equity/ distributional fairness}

As discussed above, Proclamation No. 807/2013 empowers the NBE to apply prudential regulation on financial leasing sector. NBE's regulatory approach for equipment financing sector comprises both micro and macro prudential regulations. The Proclamation's list of powers given to the NBE in respect of financial leasing companies seems rather arbitrary than a result of a careful assessment of the nature of the sector and the risks it poses on to the economy.

For instance, the powers given to NBE under Article 4(5)(c) of the Proclamation "to suspend or dismiss one or more directors or the chief executive officer of the company" appears to be unjustified in light of the systemic unimportance of a given leasing company at the micro level. The supervisory power of the NBE under this Proclamation is much more unfettered than even compared to the case for banks and insurances.

\footnotetext{
${ }^{95}$ Robert Homans, supra note 21, p. 10.

${ }^{96}$ Economisti Associati and BKP Development, Access to Finance in Ethiopia (2014), 14

${ }^{97}$ Robert Homans, supra note 21.

${ }^{98}$ Asfaw Abera Olana (2016), Lease Financing in Ethiopia: An Assessment of the Five Regulated Lease Financing Companies, MSC Thesis, Department of Accounting and Finance, AAU, unpublished, p. 45.
} 
A similar provision in the Banking Business Proclamation No. 592/2008, Article 17(1) provides that 'the National Bank may, for sufficient cause, suspend or remove a director, a chief executive officer or a senior executive officer of a bank. Sub-Article 2 of the same provision provides:

"for the purpose of sub-article (1) of this Article, 'sufficient cause' shall include the following: a) failure to comply with the provisions of Article 15 and 16 of this Proclamation; b) any action detrimental, in the opinion of the National Bank, to the stability or soundness of the financial sector, the economy or the general public interest carried out by a director, a chief executive officer or a senior executive officer a bank."

The Banking Business Proclamation does not only require good cause, but also clarifies the constituent elements of good cause. These good cause requirements are directly and indirectly related to financial health of the banking industry in which mismanagement at an individual firm level can threaten the overall sector and indirectly the wider economy. However, we do not find such good cause requirement in the financial leasing proclamation. Unlike the banking sector, equipment financing sector apparently poses by far lesser systemic risk to its own sub-sector or to the wider financial sector, and it does not pose significant risk to the overall economy. Thus the provision of such intrusive prudential requirement is ill-designed.

Likewise, the power given to NBE under paragraphs 4(5) "(a) to instruct the company to submit periodic reports; (b) to examine or cause the examination of the company onsite with or without prior notice; and (d) to take any other appropriate corrective measure" can also be questioned. The micro-prudential approach of regulation intended in these provisions is uncalled for, both by the nature of equipment financing business and the reality of the industry in Ethiopia. Equipment leasing companies in Ethiopia do not seem to warrant the type of prudential regulation envisaged in the Proclamation as the sector is at an infant stage of development.

Another instance of poorly designed requirement in the Proclamation relates to portfolio restriction. The Proclamation unnecessarily prohibits financial leasing companies from including in their portfolio operating lease. ${ }^{99}$ Restrictions on product or service lines should be placed only when circumstances clearly justify. Such restriction would have been justified if banks were allowed to enter the equipment financing sector since the justification in such circumstances would be protection of public deposit. If the reason is that MFIs that collect public deposits are allowed to do financial leasing, the scope of the restriction should have been limited to these. The restriction can on the

\footnotetext{
${ }^{99}$ See Capital Goods Leasing Business (Amendment) Proclamation No. 807/2013, Article $4(3)$.
} 
other hand result in defeating the very prudential objectives the regulatory architecture was designed to achieve. This is because the requirement can force financial leasing companies to accumulate a significant portion of dead assets when they repossess their equipment following lessees' default. If these companies are not allowed to do operating lease businesses, the accumulation of assets repossessed after a significant portion of the contract life has elapsed, can weaken a leasing company.

Even though some of these directives emanate from valid legal authority given to NBE by Proclamation No. 807, this does not preclude the need for the examination of fairness of the Proclamation itself or each of the directives emanating from it. For instance, if one looks at the Licensing Directive, it is surprising to see how minor matters are controlled by the NBE; such as age, training, reputation etc of project manager, CEO, board of directors, time limit for CEO to stay as an acting CEO, criteria to be a board chairperson, requirements for pre-application and application phases and the numerous documentary requirements, etc. In fact, the licensing directive is very similar in its content, structure and organization with the Directive for Licensing of Banking Business SBB/56/2013.

Likewise, the Directive on Limit of Exposure to a Single Lease (CGFB/09/2019) prescribes the maximum permissible size of the lease contracts. The explanations appear to be two. On the one hand is the desire to prevent a leasing company from serving few big lease applications ${ }^{100}$ thereby depleting financing for smaller ones. On the other hand, it is meant to limit the effects from the failure of a single lessee towards the lessor by diversifying default risks. ${ }^{101}$ But such interference in distributional decision making by private companies seems to be rather farfetched and unreasonable. All these regulations do not seem to serve any valid regulatory purpose in the context of independent or captive companies.

It is not clear what ground the NBE has to so tightly regulate the use of the capital of companies that are privately financed and operated. Paradoxically, this particular directive excludes the applicability of the exposure limitation provision to the five big regional state controlled leasing companies that are either wholly or predominantly financed by public funds. Indeed, if at all such a

\footnotetext{
${ }^{100}$ See 'Re: Clarification on Capital Goods Financing Policy Issues, MFISD/060/2018, Feb. 282018 ' NBE Policy Explanation Letter, to one of the license applicants. In the letter NBE clearly stated that big ticket leases, i.e., leases more than the regulatory limit of 30,000 Birr are not allowed, though the cap has been revised the policy remains the same.

${ }^{101}$ See the Preamble of the Limit on Capital Goods Finance Exposure to a Single Lessee

Directive No. CGFB/09/2019.
} 
restriction is needed, it should have been applied to the ones that manage tax payers' money; not on private companies.

Moreover, the Operational Modality Directive has introduced compulsory target market for financial leasing companies established with 400 million Birr capital. ${ }^{102}$ Accordingly, a company that is established by meeting the 400 million Birr minimum capital "shall primarily focus and provide its capital goods finance service" to SMEs and manufacturing sectors. Hence, a minimum of $60 \%$ and $65 \%$ of the leasing portfolio of such companies shall at any time constitute finance provided to SMEs, and manufacturing sector businesses respectively. In spite of the benign motive the directive emanates from, it seems unjust to burden a private business with such heavy and onerous imposition. The requirement also seems to be incongruent with prudential regulatory objectives which can be better served by portfolio diversification along various sectors.

\subsection{Outcome and Impact effectiveness}

Economic/business regulations are introduced with the view to achieving a defined set of objectives. In this regard, the capital goods financing business proclamation and the consequent regulatory regime were created with a big developmental objective. For instance, Ethiopia's Second Growth and Transformation Plan (GTP-II) "considers the equipment financing sector as a potential resource to boost employment, increase production of import substitute in goods, and accelerate a transition from agricultural led to industry led economy." "103 On the other hand, the original Capital Goods Lease Proclamation $103 / 1998$ stipulates as its objectives the creation of alternative sources of financing for those investors who have the desire, knowledge and profession to start businesses and lack the necessary capital. Proclamation 807/2013 does not, however, have a clear statement of objectives presumably because it is based on the objectives in the original proclamation as it is an amendment. Here, it is wise to distinguish between medium term outcomes and long term developmental impacts. The creation of alternative sources of financing is a medium term outcome, whereas what is stated in the GTP is a longer term developmental impact.

It is only six years since the new regulatory framework for equipment financing sector has been in place; and it may be too early to speak of developmental impacts in terms of contribution of the sector for employment generation, import substitution or for progress away from agriculture led economy to industry led one. Even if it were time to make such evaluations, this research does not claim to be well equipped to embark on developmental impact

\footnotetext{
${ }^{102}$ See Article 4 of Capital Goods Finance Operational Modality Directive No. CGFB/10/2019.

${ }^{103}$ Birritu, National Bank of Ethiopia, supra note 4, p. 32 .
} 
analysis. However, it would not require one to be genius to predict about long term impacts from the outputs and outcomes of the existing regulatory regime. If we liken the overall regulatory exercise with a particular project intervention, we can identify the creation of equipment financing enterprises and supply of services as outcome and contribution to job creation and economic development as impact.

In relation to the outcomes, creation of equipment financing enterprises and supply of services which the Proclamation envisages have not been met. With the exception of the five equipment financing companies created by the four regional states and the City Administration of Addis Ababa ${ }^{104}$, only one private sector equipment financing entity has been licensed in the second half of 2019. ${ }^{105}$ If these state owned equipment financing companies operated independently from political interference based on market principles and international best practices they would have improved access to finance to some extent. $^{106}$

However, the creation of a robust equipment financing sector cannot be realized without the emergence of a sufficient number of private sector firms that operate the business of equipment financing for profit making purposes. That requires an enabling regulatory environment conducive for a sustainable equipment financing sector. To the extent that the regulatory regime administered by the NBE has been unable to motivate the private sector, one can

${ }^{104}$ Asfaw Abera, supra note 98, p. 41; Birritu, National Bank of Ethiopia, supra note 4, p. 31; Robert Homans, Turnkey Projects' Current Status Assessment, supra note 21, p. 10.

${ }^{105}$ Kaleyesus Bekele, 'Capital Lease Company Opens Shop' 10 August 2019. Even though MFIs are generally allowed to do financial leasing, none out of the several MFIs has been reported to do that so far.

${ }^{106}$ Robert Homans' assessment made in 2018 reveals that except the Addis Ababa CGFB company, the others are overburdened by supplying equipment finance for turnkey projects in their respective regions. According to the Report, these turnkey projects were conceived the Ministry of Urban Development \& Construction, in cooperation with METEC, with the view to establishing several manufacturing facilities in various locations throughout Ethiopia using equipment financing by the regional CGFB companies with METEC as the supplier of the equipment. What transpired eventually according to the report is an unprecedented level of mismanagement and unsound business practices such as extending financing without contract. 'In other words, there was/is no binding legal relationship between the turnkey projects and the CGFBs that obligated the turnkey projects to make lease payments to the CGFBs see p. 11 . Accordingly, four of the five CGFB companies have non-performing assets in their books "that could, if the NBE as regulator, require that these assets be provisioned, result in the elimination of most or all of the equity of each of the 4 regional leasing companies that could, in turn, result in the 4 regional leasing companies being declared insolvent." Robert Homans, Turnkey Projects' Current Status Assessment, supra note 21, p. 6. 
only say that it has not produced the expected outcomes. Without the right outcomes, it cannot lead to a positive impact envisioned by the government. To achieve the positive outcome and developmental impacts, it is necessary to go back and revise the Proclamation and the directives.

\section{Conclusion and the Way Forward towards Reform}

There is an enormous market potential for growth of financial leasing sector in Ethiopia. There can be hundreds of thousands of youth with skills and good projects without the required capital to start up businesses. The equipment financing legal regime was created to stimulate the expansion of leasing firms that will enable start ups and SMEs which cannot be served by the traditional banking sector. For this potential to materialize, an appropriate enabling regulatory regime should be put in place.

On the contrary, the current regulatory environment, as discussed in this article, has created challenges rather than opportunities to achieve that purpose. While the typology of leasing firms envisaged in Ethiopia are either independents or captives of equipment manufacturers, this characteristics does not seem to feature in the regulatory instruments designed so far. A cursory view of the regulatory directives and standards developed by the NBE would compel one to think that these are designed for regulation of banks or bank owned leasing firms.

Some of these directives do not have a valid legal basis for the NBE to enact them in the first place. Some of the NBE directives seem to be rather repressive in the sense that they unnecessarily inhibit private autonomy, innovation and efficiency. The Operational Modality Directive for instance goes against the central tenets of prudential regulation by requiring high concentration of portfolio to the manufacturing sector $(65 \%)$ contrary to conventional wisdom of portfolio diversification. This calls for overhauling the entire regulatory framework. Specifically, the directives that have no legal basis, i.e., the directives on (i) the Manner of Financial and Operational Information Reporting, (ii) Limit to Exposure to a Single Lease, (iii) Operational Modality and (iv) Penalty for Failure to Comply with Regulatory Requirements should be repealed. Moreover, the restrictions on product lines and restriction of market segment (such as Micro or SME only) should be abandoned. 